症例

食道癌術後に生じた再建胃管小彎側限局性壊死の 1 例

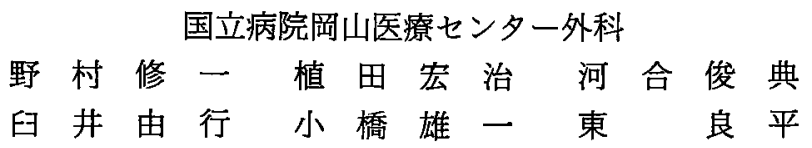

食道癌手術において再建胃管の虚血性壊死の症例を経験した。症例は70歳，男性. 第 1 期手術としての胸部食道切除ののち 3 週間目で, 第 2 期手術として大彎側亜全胃胃管 を胸骨後経路で挙上して頸部吻合を行った. 術後 3 日目, 前縦隔ドレーンの異常廃液の ため胸骨正中切開を行ったところ，胃管小䔯側縫合線の肛門側端を中心に限局性の虚血 性壊死が認められた．壊死部の切除，再縫合を行い良好に経過した。

胃壁血行は小彎側で比較的不良であり，胃管作製の際には注意深い取扱いが必要であ る.

索引用語：胃壊死，胃管，食道癌

はじめに

食道癌手術で再建用胃管の血行はその口側端が問題 とされるが，この度大彎側重全胃胃管の比較的肛門側 の小彎に虚血性壊死を生じた症例を経験した. 再建用 胃管の作製においては小繁側血行にも注意が必要であ ることを指摘した。

$$
\text { 症例 }
$$

症例：70歳, 男性.

主訴：嬩下時違和感。

既往歴：肺気腫, 糖尿病.

現病歴：平成 9 年 7 月初旬から食べ物がのどにひっ かかる感じがあり，当院内科を受診して胸部食道癌を 指摘され 7 月28日内科入院となった. 高血圧症はなく， また，特に服楽はしていなかった。

入院時現症：身長 $168 \mathrm{~cm}$ 体重 $51 \mathrm{~kg}$, 瘦せ型, 頸部り ンパ節腫脹なし.胸部腹部に理学的異常所見を認めず.

検查成績：一般血液・生化学検査では特記すべき異 常所見はみられず.胸部単純 $\mathrm{X}$ 線では両肺の X線透過 性は高く, 横隔膜は低位にあって肺気腫像を呈した。 呼吸機能検査では 1 秒率 $73 \%$ と低下していた。胸部上 部食道には 0-IIC 型の食道癌が認められた。

狭心症があり，入院後冠動脈造影を行ったところ，

2002年11月21日受付 2003 年 3 月 28 日採用

〈所属施設住所〉

テ701-1192 岡山市田益1711-1
右冠動脈に有意狭窄 1 力所を認めるも処置を要するも のではないと判断された。

\section{入院後経過}

肺, 心のことを考慮して食道癌に対して 2 期分割手 術を行った。

第 1 期手術：右開胸で胸部食道を切除し, 形部食道 瘦, 空腸瘦を造設した. 術後は順調であった.

第 2 期手術：21日後に消化管再建術を行った.上腹 部正中切開で開腹し大彎側业全胃胃管を作製した。胃 管は胸骨後径路で挙上し, 頸部で食道・胃管端側吻合 を手縫いで行った。病理診断は, 中分化扁平上皮癌, p-T1b (SM) N0, M0, p-stage I, 郭清度は D1であ った.

胃管は下記のごとく作製した(図 1). 右胃大網動脈 全長と右胃動脈（胃固有枝 2 枝）を栄養血管とした。

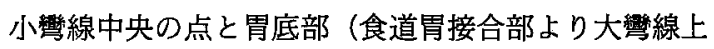
$5 \mathrm{~cm}$ の点）を結ぶ直線で自動縫合器を用いて胃壁を 切離して大繁側亜全胃胃管を作製した。切離縁には奬 膜筋層結節縫合を加えた。胃管小彎側には, 切離端と 残置小網との間に,血行郭清され墏膜を欠いた部分(小 彎線上で約 $5 \mathrm{~cm}$ の範囲)が存在した。しかしこの部に 色調不良はみられなかった. 胃管栄養動脈の拍動は良 好であった。

術後経過: 術後 3 日目, 前縦隔ドレーンの排液異常 から胃管造影検查をしたところ，胃管の肛門側部分か らの造影剤の漏出が認められた．胸骨の下半分を正中 


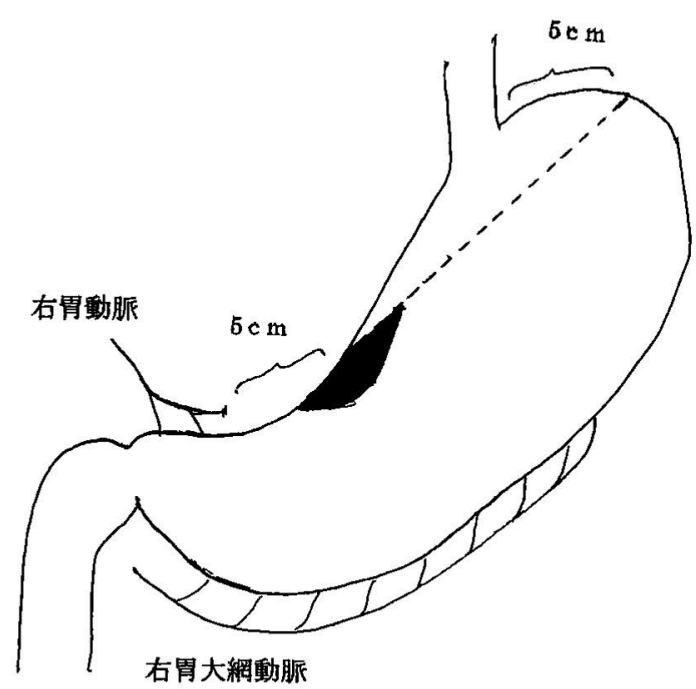

図 1 作製した大彎側胃管と壊死部

切開して胃管を露出したところ, 胃管小彎側縫合の肛 門側端で全層壊死を含む胃壁の壊死が認められた（図 $1,2)$. 壊死部切除再縫合を行って狭窄を生じなかっ た. 肉眼所見と病理所見から, 成因は虚血であると考 えられた. その後の肺合併症により退院は術後約 4 力 月後となったが, 術後約 5 年半の現在無再発生存中で ある。

\section{考 察}

食道癌手術において胃管壊死といえば口側端に生じ るものと考えられており, 本例の如く胃管の途中に生 じたとの報告は調べ得た限りではなく，稀なことと考 えられる.

胃の壊死の病因としては, (1) 胃の感染 (2) 胃の 高度拡張 (3) 化学物質の誤嚥, (4) 胃の阻血が挙げ られる. 本例では, 臨床経過と手術所見から見て阻血 性壞死と考えられる ${ }^{1)}$.

胃は壁内血管の交通が極めてよく発達しており, 他 の消化管ほど神経質にならないで血管処理を行ってい る.しかし胃壁の血行には, Barlow が切除胃のマイク ロアンギオグラフィーで示しているように，外科医と して注意すべき特徵がある2).すなわち，大彎，前壁， 後壁の血行は豊富な壁内側副血行により，かなりの血 行郭清に絶えられるのに対して，小彎扔よびその 1 $\sim 2 \mathrm{~cm}$ 前後の範囲では壁内血管網の発達が悪く, 互 いの交通は, 筋層にはいる前の動脈枝間に依る傾向が あることが知られている334). したがって，小樂側の血 管処理を漿膜下で広く行うとその部の胃壁は阻血に陥

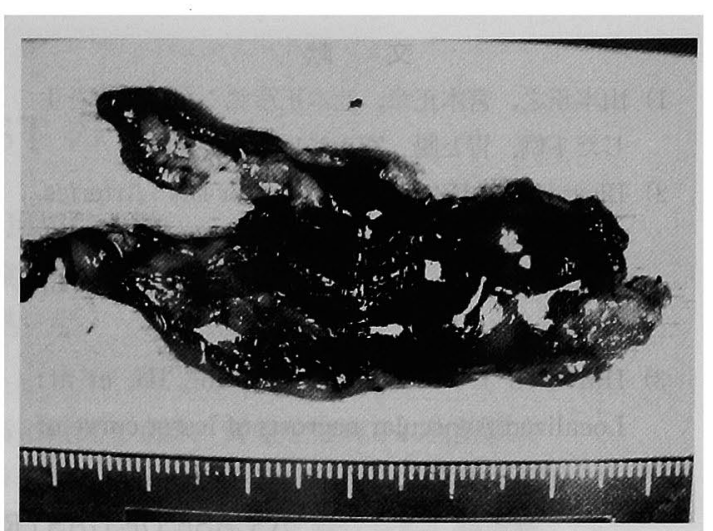

図 2 切除した胃壁壊死部（粘膜面）

りやすいという事になる．このことは胃の選択的迷走 神経切離術の術後合併症としての胃小彎壊死で示され ている5). 迷走神経を全く失っている点でも胃管は迷 走神経切離術後の胃と似ている.

また，胃壁血行に影響を与える要因として動脈硬化 性変化を考えておかねばならない．本例では術中の肉 眼所見, 術後の病理所見でも有意の変化を認めてはい ないが, 胃管血行を阻害する因子として常に注意して おくべきである。

食道癌切除後の胃管作製をどのようにするかについ ては多くの方法と工夫が発表されているが，そのなか でも問題は胃管の太さの問題である。一般に太い贯管 は壁内血管網が広く温存されるため口側端の血行がよ く,縫合不全が起きにくいとして広く採用されている. しかし，太い胃管ほど小彎が血行郭清のまま長く残る ことになり，胃管のなかに阻血部分かかえることにな り，太い胃管のひとつの弱点になり得る.

太い胃管を作製するとき, 頻度の低い合併症であろ うが本例のようなことが起こらないように予防するに は以下の注意が望まれる。（1）血行郭清した部分の小 彎はそのまま長く残さないで噴門部に含めて切除する こと, (2)小彎側の血管処理は, 胃壁に余り近づきす ぎないようにし，漿膜をできるだけ残し筋層露出を少 なくすること，（3)露出した筋層は漿膜筋層縫合か大 網をあてるかして腹膜化しておくこと，(4)胃管内外 のドレナージを確実にしておくこと，である．

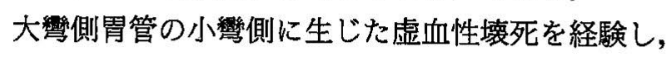
作製に当たり注意すべきことをのべた。

なお, 本論文の要旨は第139回岡山外科会 (平成11年 6 月 19日, 岡山) で発表した。 


\section{文献}

1）山本正之, 宮本正章, 辻本正彦他：全胃壊死を生 じた 1 例。胃と腸 $23: 311-316,1988$

2) Barlow TE, Bentley FH, Walder DN : Arteries, veins, and Arteriovenous anastomoses in the human stomach. Surg Gynecol Obstet $93: 657$ $-671,1951$

3) Halvosen JF, Heiman P, Solhaug JH, et al: Localized Avascular necrosis of lesser curve of stomach Complicating highly selective vagotomy. Br Med J 2:590-591, 1975

4）貴島政邑，松島孝雄，阿南 晃他：食道再建用胃 管の太さと口側末梢の壤死. 外科 $45: 1551-$ 1555,1983

5) Johnston D: Operative mortality and morbidity of highly selective Vagotomy. Br Med J 4 : $545-547,1975$

\title{
A CASE OF GASTRIC TUBE NECROSIS OF LESSER CURVATURE AFTER AN OPERATION FOR ESOPHAGEAL CANCER
}

\author{
Syuichi NOMURA, Koji UEDA, Toshinori KAWAI, Yoshiyuki USUI, \\ Yuichi KOBASHI and Ryohei HIGASHI \\ National Okayama Medical Center
}

\begin{abstract}
A case of ischemic gastric tube necrosis after surgery for esophageal cancer is described. A 70-year-old man underwent a cervical esophagogastrostomy 3 weeks after a resection of esophageal cancer. Greater cuvature gastric tube was provided with a partial resection of lesser curvature and fundic portion, and was brought to the neck retrosternaly. Perforation of the stomach was discovered by abnormal discharge from a mediastinal drainage tube on the third postoperative day. A midline sternotomy revealed ischemic gastric necrosis localized around the anal end of suture line applied on the lesser curvature. Necrosectomy and resuture closure were satisfactory.

Preparation of a gastric tube from the greater curvature requires careful procedure because of relatively poor blood circulation in the lesser curvature of the stomach.
\end{abstract}

